\title{
A MAGYAR RORSCHACH-RENDSZER REVÍZIÓJA ÉS AZ ÚJ, SINE MORBO STANDARD
}

\author{
MOLNÁR FERENC \\ Szegedi Tudományegyetem ÁOK, Szent-Györgyi Albert Klinikai Központ, \\ Pszichiátriai Osztály \\ E-mail: molnarf@gmail.com \\ Beérkezett: 2019. december 31. - Elfogadva: 2020. február 1.
}

Háttér és célkitûzés: A Rorschach-teszt idôszerüvé vált új, sine morbo standardját 2007 és 2014 között a Szegedi Tudományegyetem Pszichológiai Intézetének független kutatócsoportja készítette el. A standardizálás elókészítô és kezdeti szakaszában felülvizsgáltuk a magyar Rorschach-rendszert, jelölési alapelveket fogalmaztunk meg, módosítottunk néhány jel alkalmazásán, újakat is bevezettünk.

Módszer: A kutatásban a pszichiátriailag sine morbo, felnôtt személyek önként vettek részt, életkoruk 18 és 75 év közötti volt, iskolai végzettségük az általános iskolástól a többdiplomásig terjedt, és 118 település lakói közül kerültek ki. Az alapvetô független változók kategóriáiból 32 almintát állítottunk össze, a teljes minta 1500 föbốl állt.

Eredmények: Az eredmények alapján vagy megerôsítttük, vagy módositottuk a mutatók korábbi jellemzố értékeit és övezeteit, meghatároztuk az új mutatók referenciaértékeit, a feleletszám eltérô hatását a jelekre és mutatókra, összeállitottuk az új vulger válaszok listáját, támpontokat nyújtottunk a lokális értelmezéshez.

Következtetés: Rorschach-rendszerünk revíziója és az új standard adatai a Rorschach-teszt szükséges és elkerülhetetlen továbbfejlesztését szolgálják, validitását erösítik, reliabilitását növelik.

Kulcsszavak: sine morbo standard, új jelek és mutatók, a Rorschach-teszt továbbfejlesztése 


\section{BEVEZETÉS}

Bár a Rorschach-táblák a kezdetektôl ugyanazok, és sohasem avulnak el, a rájuk adott válaszok az idô múlásával változó tendenciákat mutatnak. Ezért a társadalmi változások mértékétôl és ütemétôl függôen idôrôl idôre új referenciákat kell nyújtani a jegyzôkönyvek feldolgozásához, az értelmezéshez, azaz el kell készíteni az újabb standardot. Pszichológus kollégákkal és felsôbbéves hallgatókkal a Szegedi Tudományegyetem Pszichológiai Intézetének független kutatócsoportjaként ${ }^{1}$ erre vállalkoztunk 2007-ben, és 2014-ben fejeztük be kutatásunkat. A standardizálást közel 1 év elôkészítô munka elôzte meg, amelynek részeként elôzetes tanulmányainkat követôen a londoni Tavistock Központ két pszichológusa, Justine McCarthy Woods és Sadegh Nashat egy tanfolyam keretében mélyebben és részletesebben megismertette velünk az Exner (2003) által kidolgozott, empirikusan jelentôsen alátámasztott, napjainkban a legtöbb országban használt Rorschach-rendszert, a Comprehensive Systemet (CS). Ezzel eredetileg az volt a célunk, hogy Mérei (2002) egyedülálló részletességgel és alapossággal megalkotott, hazánkban széleskörúen alkalmazott Rorschach-módszere mellett a CS magyar standardjával alternatívát nyújtsunk a kognitív szemléletú szakemberek számára. Rá kellett azonban jönnünk, hogy a két rendszer közötti jelentôs különbségek áthidalhatatlan szakadékot képeznek, például a felvételi technika eltérései miatt lehetetlen ugyanazoknak a jegyzôkönyveknek mindkét rendszer szerinti feldolgozása, így a CS szerinti standardról le kellett mondanunk.

A teszt használata során arra kell törekednünk, hogy a lehetô legtöbb információt nyerjük általa. Ha olyan válaszokat kapunk, amelyek kódolására a jelrendszerünk nem bizonyul maradéktalanul elegendônek, új jeleket kell bevezetnünk. Ezt tettük mi is, amikor több új jel kidolgozása mellett döntöttünk. Legnagyobb részük értelmezése levezethetô a magyar rendszer összefüggéseiból, de olyan is van, amely hipotetikus maradt. Alapelveket fogalmaztunk meg a jelölésben, és néhány korábbi jel alkalmazását szigorúbb feltételekhez kötöttük, hogy elkerüljük értelmezésük inflálódását. A magas elemszám nyújtotta lehetôségeket maximálisan igyekeztünk kihasználni, minden olyan mutatóhoz, amelynek empirikus alapja van, új táblázatot készítettünk, és ha kellett, új övezeteket határoztunk meg.

A Rorschach-teszt nem lezárt rendszer, és sui generis soha nem is lesz az. Minden újrastandardizálás elkerülhetetlenül a teszt továbbfejlesztése is egyben.

\footnotetext{
A kutatócsoport tagjai voltak: Balázs Éva, Balogh Virág, Boros Tünde, Csák Ildikó, Csizmár Orsolya, Décsey Dóra, Feketéné Zsigó Marietta, Fenyvesi Tamás, Ferencz Valéria, Gellért Lívia, Gyulai Devánszki Éva, Hangyál Tamás, Héjja Annamária, Horváth Diána, Juhász Anikó, Juhász Anita, Kígyós Tamás, Kis Andrea, Kiss Márta, Kocsis Kata, Kovács Anita, Kovács Dóra, Krisztián Mariann, Látos Melinda, Lázár Eszter, Lázár Krisztián, Lehoczki Andrea, Matusik Krisztina, Mészáros Árpád, Mohácsi-Hartner Judit, Molnár Ferenc, Molnár Zsuzsa, Nagy Tamás, Nyíri Sándor, Pomázi Petra, Puskás Barbara, Rafael Beatrix, Rácz Zsuzsanna, Selmecziné Valach Renáta, Semsey Zsuzsanna, Szabó Anikó, Szalai Emma, Szeredi Emese, Szilágyi Edit, Udvarhelyi Boglárka, Vámos Barbara, Weisz Katalin.
} 


\section{A MAGYAR RORSCHACH-RENDSZER REVÍZIÓJA}

Ebben a részben jelölési alapelveinket, kiegészítéseinket és változtatásainkat, valamint az újonnan kidolgozott jeleket ismertetem. Ez utóbbiak értelmezése a standard eredményeit is részletesen tartalmazó Segédkönyvben található (Molnár, Vámos, Lázár, Rácz, Décsey és Csizmár, 2014).

Módosításaink összhangban vannak Mérei rendszerével, amely jól használható a mi tapasztalataink szerint is, ezért jelentôsebb változtatásra nincs is szükség. Az új jelek bevezetésével, a differenciáltabb jelöléssel a teszteredményekbôl levonható következtetések validitását és reliabilitását szándékoztunk növelni.

Ez a cél vezérelt bennünket akkor is, amikor elvetettünk néhány olyan jelölési konvenciót, amelyet évtizedeken át automatikusan alkalmaztunk, most viszont szigorúbb feltételekhez kötöttük a DGkomb, a DGkonf és a B jelölését.

A validitási mutató kidolgozásával a jegyzôkönyvek értelmezhetôségének megállapításához az eddigi szubjektív szempontokat objektívekre cseréltük.

\section{Jelölés}

\section{Alapelvek}

A percepcióban és a jelentésben egyaránt önálló egységek külön determinánst kapnak.

Egy válaszban csak az egymástól egyértelmúen elkülönülố területek tartoznak önálló perceptuális egységbe. Ez áll fenn, ha két folt nem érintkezik egymással, vagy érintkezik, de színében vagy árnyalatában különbözik. A jelentésben elválaszthatatlanul összetartozó részek egy egységet alkotnak. Az embernek vagy állatnak a testrészei vagy a belsô szervei, a hajótest és a vitorla, a fatörzs és a lomb összetartoznak, ezért nem kapnak külön-külön determinánst. Az embertől a szemüveg, az indiántól a tolldísz, a repülootoól a tûzcsóva, a lámpától a fény viszont már elválasztható, ezek önálló jelentési egységek. A jelentés nem azonos a tartalommal, egy jelentés több tartalmat is magában foglalhat, és fordítva, egy válaszon belül több jelentésre is vonatkozhat ugyanaz a tartalmi jel.

Egy jel egy válaszban csak egyszer adható.

Ez az elsố alapelv érvényességét korlátozza. Kivételt a negyedik oszlop, valamint a Rejtett értelmezés és a Juxtapozíció jelent. Ez utóbbiaknál az összekapcsolt jelentések egy válaszba tartoznak, de többször is kaphatják ugyanazt a jelet. Az eltérô adekvációs fok nem jelent külön determinánst, ilyenkor mérlegelni kell, hogy milyen adekvációt jelöljünk.

Példák: III. Két nôre (egész) emlékeztet, akik egy edénybe $(1,13)$ nyúlnak. (a két nô és az edény is: forma) $\mathrm{G} \mathrm{B}+, \mathrm{F}+\mathrm{M}, \mathrm{Obj} \mathrm{V} 1, \mathrm{~V} 3$

IX. A pokolban (egész) két ördög (1) van. Olyan, mintha egy nagy katlanban (2) volnának. Alattuk ég a túz (3). (ördögök és katlan: forma, túz: szín és forma) Gkomb

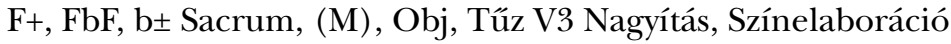




\section{Felfogásmód}

DGkomb

A DGkomb a magas intellektuális színvonal jele, ezért az értelmezésével összhangban akkor jelöljük, ha legalább három jelentésbôl épül fel a válasz. Természetesen a többi feltételnek is teljesülnie kell.

A VIII. táblán a jegyzókönyvek 95\%-ában előforduló négylábú állatnak csak egyetlen jelentéssel történô összekapcsolását nem tartjuk a kiemelkedô kombinatív készség megnyilvánulásának, ezért az ilyen válaszokra nem jelöltünk DGkombot vagy az ötödik oszlopban Kombinációt.

\section{DGkonf}

Jelölésének egyik feltétele, hogy a kiterjesztés szubjektív, önkényes, a létrehozott jelentés nem felel meg a formának. Ebbôl következôen vulger jelentésre nem adtuk, mert amit viszonylag sokan látnak ugyanazon a területen, az nem lehet önkényes. Ilyen például az I. táblán a bogár (egész) válasz, amely G jelet kapott, szemben a Mérei-féle egész válaszra adott Dgkonf jellel. Az I. táblán ugyanis Mérei csak az 1-es lokalizációra adott „bogár válaszra” adott D-t, az egészre DGkonfot jelölt. A Vargha, Császár-Nagy és Bagdy (2014) -féle új vulgerben az emberek 20\%-a mond bogarat az egész I-es táblára, ott ez V2 gyakoriságnak számít.

Do (D) és Do (Dd)

A Felfogótípus és a szukcesszió miatt tartjuk szükségesnek a kettô megkülönböztetését. A Do-t eddig a Felfogótípusban egyik csoportba sem soroltuk, a szukcessziónál pedig minden esetben a Dd-csoportba került. Például a IV. táblán a 4-es területre az önálló csizma válaszra D-t jelölünk, míg a lábra Do-t. Korábban ez utóbbit az FT csoportosításnál figyelmen kívül hagytuk, a szukcessziónál a két válasz különbözố csoportba tartozott, jóllehet ugyanarra a területre terjed ki. A Do-t ezért differenciáltan jelöljük, és ennek alapján vesszük figyelembe az említett két mutatónál.

DzwDd, DdzwD, DdzwDd

Ezeket a jeleket a hazai jelölési gyakorlatban már általánossá vált DzwD mintájára alkalmazzuk.

\section{Változások a lokalizációban}

A DzwD, DzwDd, DdzwD és DdzwDd jelek használata szükségessé tette, hogy újragondoljuk a VIII. és IX. tábla bizonyos részeinek felfogásmódbeli jelölését. Arra a következtetésre jutottunk, hogy a választól függóen vagy a foltot, vagy a hátteret jelöljük a lokalizációs táblán ugyanazzal a számmal jelzett területre. A VIII. tábla 6-os részletén az emberfej, állatfej, a maszk, c állásban a két térdelő ember Dzw jelet kap. A bordák, a halgerinc, a tenyérvonalak D-t. DzwDd-t jelölünk a búgócsigára $(6,8)$ vagy c állásban a karácsonyfára $(6,8)$. 
A IX. táblán a 4-es területen Dzw a serleg, a pohár, a tó, c állásban a harang, a villanykörte, a sakkbábu. DzwD-t jelölünk a háttal ülô emberre $(4,16)$, akinek 16 a gerince, a homokórára $(4,16)$ vagy c állásban a villanykörtére $(4,16)$, ha 16 az izzószál, és a hegedûre, csellóra, gitárra, ha 16 a húrjai. Ha a 21-es Ddzw terület is jelentést kap a válaszban, a 4-es rész D lesz, tehát a jelölés DdzwD-re módosul. Ilyen az állatfej, az orr (mindkettônél 21 az orrlyuk), az almacsutka (21 a mag) vagy c állásban a szellem (21 a szem). Szintén ezt jelöljük a következô válaszra: „Üveget (4) is látok, két kis hal (21) van benne.” A IX. tábla 20-as területét Dd-re változtattuk. Ezt kapta a korona, a gomba, az ajtógomb, az üveggömb. A 21-es területtel együtt így Dd, zw lett az álarc, valamint a Halloween-tök, és DdzwDd az emberfej (21 a szem, továbbá az orr, 21 az orrnyílás).

\section{Determinánsok}

\section{Hézagkitöltéses B}

A B+ a Rorschach-vizsgálat egyik legértékesebb jele, ezért Bohm (1985) intelmével egyetértve mi is igyekeztünk elkerülni túljelölésének veszélyét. Nyomon követtük a hézagkitöltéses B létrejöttének folyamatát, ami Rorschach (1998) intuíciójából indult ki, aki elsôdleges és másodlagos embermozgást különböztetett meg, de nem a mai értelemben használt B-re és Bsec-re gondolt, hanem arra, hogy elôször a mozgás vagy a forma észlelése történik-e. Az elsôdleges embermozgásra említi példaként a III. tábla hézagkitöltését: „Az elsôdleges kinesztéziás tényezôk nagy valószínúséggel szükségesek ahhoz, hogy lehetôvé váljon a vizsgált személy számára ennek az elkülönülésnek a figyelmen kívül hagyása" (Rorschach, 1998, 25).

Tarcsay (1940) könyvében - amely a teszt elsố hazai bemutatása - az elsôdleges és másodlagos mozgás még megtalálható, de már nincs benne Rorschachnak ez a példája a III. tábláról, és még szó sem esik a hézagkitöltéses B-rôl mint elvrôl.

Mérei (2002) a következóket írja: „Pregnáns alakzatok percepciója esetén a hiányt a szemlélet (és nem a képzelet!) tölti ki. A pszichológiai feltevés szerint ezek a hézagok csak úgy tölthetôk ki, ha a figurát mozgásban látom” (Mérei, 2002, 56).

A perceptuális szervezôdés gestaltpszichológiai törvényeit alkalmazva kutatócsoportunk a biológiai értelemben vett jó folytatást megfelelóbbnek gondolta, és empirikus adatainkat is figyelembe véve, amelyek szerint a nem hézagkitöltéses $\mathrm{B}$ a magasabb, míg a hézagkitöltéses B - föleg kizárólagosan - az alacsonyabb végzettségúek jegyzókönyvében fordult elô nagyobb számban, megszüntette a hézagkitöltéses B alkalmazását.

$(\mathrm{Fb}) \mathrm{F}$

A jelentésadást a színárnyalat vezérli, a forma másodlagos jelentôségú.

Ezt a jelet kapja a IX. táblán a füst (3), a vízesés $(16,26)$, amire FbF-et is jelölünk vagy a X. táblán a felhố (10). 


\section{Tartalmak}

Implicit tartalom

A magyar Rorschach-rendszer szemléletmódjából következik, hogy a felvétel és az utóteszt között éles a különbség. Ezért az utótesztból csak a szemléletet pontosító, kiegészítô információkat fogadjuk el. Implicit tartalomról beszélünk abban az esetben, ha a vizsgált személy a felvétel során nem nevez meg egy olyan tartalmat, amely a megfogalmazás alapján a szemléletében biztosan jelen volt.

II. Két veszekedó medve (1). (veszekednek, mert ott a vér (3); két medve: forma, vér: szín és forma) D BF+ FbF T, Vér V1, V3 Intenció, Agresszió

Implicit tartalomra Színelaborációt nem jelölünk.

A Szem és a Szex nem lehet implicit tartalom, mert az értelmezésükkel összeegyeztethetetlen, de a determinánsoknál figyelembe vesszük.

IV. Ez valami állatnak a feje (1). (17 a szeme; forma és árnyékolás) D FHd+ Td Unbestimmt

Felvétel

Akkor jelöljük, ha a válaszban fénykép, negatív, múholdfelvétel, hôtérkép vagy más felvétel szerepel. Mivel a válaszokban valakirôl vagy valamirôl készült felvételek fordulnak elő, más tartalmi jelekkel együtt adjuk. A gyógyászatban használatos digitális képalkotó eljárásokkal (CT, MR, UH, PET) készült képek, valamint a thermográfiás diagnosztikához tartozó hôkamerás felvételek Rtg jelet kapnak.

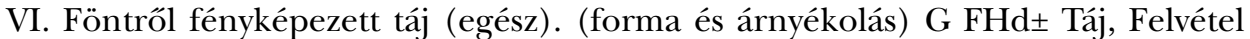
Távolítás

VII. c Egy medúzának (14) a negatívja. (forma és fehér szín) Dzw aFFb+ T, Felvétel Élettelenítés

VIII. c Napkitörés (2) múholdfelvételen. (szín és forma, színárnyalat és forma) $\mathrm{D}$ FbF, $(\mathrm{Fb}) \mathrm{F}, \mathrm{b} \pm$ Asztronómia, Explózió, Felvétel

\section{Különleges reakciók}

nFb-utalás (Elaborációk)

A válaszadás során az akromatikus foltoknál a személy a szürke vagy fekete szín megnevezését rámutatásra, lokalizálásra használja fel. A Hd-utalástól kell megkülönböztetnünk, amit elsôsorban a vizsgált személy szóhasználatára hagyatkozva tehetünk meg.

III. Ez olyan, mintha két emberalak (egész) lenne, ez a két fekete. (forma) G F+ M V1 nFb-utalás

VII. El tudnám képzelni szigetként (egész) a feketéket. (forma) G,zw F \pm Térkép nFb-utalás

nFb-ütközés (Elakadások)

Akromatikus táblákon a vizsgált személy kifejezi, hogy a foltok szürke-fekete színe zavarja. 
IV. Csúnya fekete, a színe miatt nem tudok semmit mondani. Komor.

V. Nyomasztóan fekete színe van mindenhol.

VII. Nem szeretem ezeket a ronda szürke színeket!

Morbiditás (defekt reakciók)

Akkor jelöljük, ha a válaszban halott ember vagy állat, illetve halállal kapcsolatos más jelentés fordul elô.

II. Fent egy koporsóféle (4) látszik még. (forma) D F \pm Obj Morbiditás, Unbestimmt

VI. Kilapított róka (egész) is akár. Átment rajta egy gôzös. (forma és árnyékolás) G FHd+, Asszoc B T V1 Deformálás, Morbiditás, Fokozott jelentéstudat

X. Leginkább egy halottra $(3,10,24,25,27)$ hasonlít. (forma) DzwD F+ M FH+, Morbiditás

\section{Mutatók}

\section{Validitás}

A feldolgozás során találtunk néhány jegyzókönyvet, amelynél erôs kételyek merültek fel, hogy a vizsgált személy elérte-e a laza jelentésadáshoz szükséges oldott állapotot. Szükségessé vált egy validitási mutató kidolgozása, amely alapján dönthetünk a jegyzôkönyv értelmezhetôségéról.

Teoretikus megfontolásból a Feleletszámot, a Tartalmi körök számát és a Formaválaszok preferenciáját vizsgáltuk. Ez utóbbit Mérei (2002) az izolációs elhárítás jellemzôi közé sorolta, mi az alacsony végzettségüek jegyzókönyveiben is találtunk több kiugróan magas értéket, valamint olyan esetekben, amikor a vizsgálati személy nem tudott vagy nem akart involválódni, amikor védekezó attitúdöt képviselt.

Az empirikus adatok felhasználásával végül a validitás kritériumai a következôk lettek:

1. Feleletszám: minimum 8

2. Tartalmi körök száma: minimum 2

3. Ha a tisztán Formaválaszok aránya a többi válaszhoz az átlag és a szórásérték kétszerese összegének övezetén kívül esik, azaz nagyobb, mint 0,99+2×0,71 = 2,41, akkor a Feleletszám + Tartalmi körök száma - Formaválaszok aránya $\geq 10$.

Ha bármelyik feltétel nem teljesül, a felvétel érvénytelen. Ezeket a jegyzőkönyveket kihagytuk a statisztikai feldolgozásból, nem kerültek be a standardba.

\section{Indulati feszültség}

Az Indulati Típus két oldalának összege, ami korábban is az értelmezés egyik szempontja volt, most ez a feleletszámot is figyelembe vevô referenciaértékekkel pontosabbá vált. 


\section{MÓDSZER}

\section{Minta}

A mintába pszichiátriailag sine morbo felnôtt személyek kerülhettek. Elsô megközelítésben sine morbónak tekintettünk mindenkit, aki a felvétel idôpontjában nem állt pszichiátriai kezelés alatt. Ezután kihagytuk a feldolgozásból azokat a jegyzókönyveket, amelyekben kettônél több Versagen fordult elô, és azokat is, amelyeket klinikai tapasztalataink alapján sine sanitaténak tartottunk. Ugyanakkor ez a kutatás is igazolja, hogy a pszichiátriailag sine morbo kategória relatív, mert számos jel gyakoriságának és több mutatónak olyan szélsôséges értékét is megtaláljuk, amely nem az egészséges múködésre jellemzô. Ha azonban minden ilyen jegyzókönyvet kizárnánk, a lelki egészség fogalmát életszerútlenül leszúkítenénk. Kimaradtak viszont azok a jegyzôkönyvek is, amelyek nem feleltek meg az újonnan kidolgozott validitási feltételeknek.

A minta összeállításában a nemet, életkort, iskolai végzettséget és lakóhelyet kezeltük független változóként. Az elemszám 1500 lett, 761 nô és 739 férfi jegyzókönyve került a standardba.

Életkor szerint négy övezetet különböztettünk meg: 18-27 évesek (383 fơ; átlag: 22,14 év; szórás: 2,98 év), 28-39 évesek (372 foo; átlag: 33,26 év; szórás: 3,48 év), 40-59 évesek (374 fő; átlag: 49,02 év; szórás: 5,79 év), 60-74 évesek (371 fő; átlag: 65,81 év; szórás: 4,24 év). A felosztásban Erikson (1988) elgondolásait követtük azzal a különbséggel, hogy a fiatal felnôttkort két szakaszra bontottuk. A vizsgálati személyek életkorának átlaga 42,40 év (szórás: 17,03 év).

Iskolai végzettség tekintetében az egymásra épülő képzéseken elvégzett osztályok, befejezett évek száma alapján szintén négy kategóriát különítettünk el: 0-8 osztály (364 fő), 9-11 osztály (374 fö), 12-14 év (385 fö), legalább 15 év (377 fő).

A nem, életkor és iskolai végzettség kategóriáinak kombinációiból $2 \times 4 \times 4=32$ almintát hoztunk létre, és a standardon belüli aránytalanságok elkerülése érdekében minden almintába legalább 45 és legfeljebb 50 érvényes felvétel került.

A lakóhely vonatkozásában a területi elhelyezkedést és a település nagyságát vettük figyelembe. Az ország 7 régiójának mindegyikében 6 övezetet különítettünk el a lakosság lélekszáma alapján, így összesen 42 településkategóriát hoztunk létre. Ezekbôl a mintába olyan arányban kerültek vizsgálati személyek, amilyen az aránya az adott régióban és településövezetben élôknek az ország lakosságához képest. Bár tervünket ebben a tekintetben nem sikerült teljes mértékben megvalósítani (minél nagyobb egy település, annál nehezebben boldogultunk), a mintavétel több mint 90\%-ban megfelel a lakosság területi eloszlásának.

Budapestet az MMPI korábbi standardizálásának (Pressing és Szakács, 1990) megfelelôen 9 kerületcsoportra osztottuk, amelyekbôl az ott élôk számával arányosan választottunk vizsgálati személyeket.

A standardhoz 118 település lakóinak jegyzókönyvét használtuk fel.

Törekedtünk arra is, hogy a vizsgálati személyek alapvetô változók (nem, életkor, végzettség) szerinti eloszlása a településkategóriákban kiegyenlített legyen, azt pedig feltételként szabtuk, hogy egy településról (Budapesten egy kerületcsoportból) egy almintába legfeljebb három személy jegyzôkönyve kerülhetett. 


\section{Statisztikai feldolgozás}

A legtöbb jelnél és mutatónál csak leíró statisztikai adatokra van szükség, ezek közül az átlag a legfontosabb, de táblázatba foglaltunk néhány további releváns adatot is: a szórást, a legkisebb és legnagyobb értéket, a mediánt és a móduszt.

Az abszolút számokból álló és arányban kifejezett mutatóknál (ÉT, MF, IT, M:Md, T:Td, V1:[V2+V3]) a két oldalnak külön-külön számoltuk az átlagát, amit az adott mutatóban használatos formára kerekítettünk.

A feleletszám mint független változó és az abszolút számokat tartalmazó mutatók közötti függvényszerú kapcsolatot egyszerú lineáris regressziós modellel határoztuk meg, és a korreláció erôssége alapján három kategóriát különítettünk el.

A Felfogótípus csoportosított jelei táblázatának kialakításához szintén a kétváltozós lineáris regressziós modellt alkalmaztuk, ahol a független változó a feleletszám, a függô változó a $G, D, D d$ és zw csoport jeleinek jegyzôkönyvenkénti száma, valamint az adott feleletszámhoz tartozó jegyzôkönyvekben számolt szórása volt. Az FT értelmezésének alapja és kiindulópontja az az elméleti megfontolás, hogy az átlagos FT-ben a G és a D kiírva szerepel (Mérei, 2002). Mivel ez sine morbo standard, és a további alapvetô független változók (nem, életkor, végzettség) tekintetében kiegyenlített mintára épül, az elôzôekbôl következik, hogy táblázatukat úgy kellett elkészíteni, hogy annak alapján a G és D a jegyzőkönyvek megközelítôen 50\%-ában kiírva, 20-20\%-ában zárójelben, illetve egyszer aláhúzva, 5-5\%-ában nem jelölve, illetve kétszer aláhúzva forduljon elö.

A csoportosított Dd és zw, valamint a kiegészító jelek esetében azonban más a helyzet. Mivel az idetartozó jelek a jegyzôkönyvek jelentôs részében egyáltalán nem, vagy csak csekély számban találhatók meg, táblázatuknak a G-hez és D-hez, valamint egymáshoz viszonyított gyakoriságukhoz kell igazodnia, és a feleletszámmal való összefüggés az alapjuk.

Az FT-táblázatok elkészítése után meghatároztuk az egyes jegyzókönyvek Felfogótípusát, majd ezek statisztikai feldolgozása révén adtuk meg a standard jellemzô FT-jét, ami a csoportosított és kiegészítő jelek mediánja volt.

\section{Etikai vonatkozások}

A vizsgálati személyek önként vettek részt a kutatásban, anyagi juttatást nem kaptak, és elốre megbeszéltük velük azt is, hogy az eredményeikrôl nem tudunk visszajelzést adni. Személyes adataik közül a nevüket nem kellett közölniük, csak az életkorukat, iskolai végzettségüket és lakóhelyüket kértük. A kutatást a Szegedi Tudományegyetem BTK Pszichológiai Intézetének etikai engedélyével végeztük.

\section{FONTOSABB EREDMÉNYEK}

Ebben a tanulmányban terjedelmi okból csak a fontosabb eredményeket, a leíró statisztikai adatok közül csak az átlagokat foglalom táblázatba. 
1. táblázat. Mutatók átlagértékei

\begin{tabular}{l|c|l|c}
\hline Mutató & Átlag & Mutató & Átlag \\
\hline Feleletszám & 25,21 & Színes Index $\%$ & 34,22 \\
\hline IIdô (min) & 18,12 & Idô/Feleletszám & 0,77 \\
\hline F1+\% & 85,30 & F2+\% & 85,16 \\
\hline Tartalom szóródása & 1,29 & Tartalmi körök száma & 11,54 \\
\hline M \% & 15,71 & M : Md & $2: 1^{*}$ \\
\hline T \% & 52,80 & T : Td & $11: 1^{*}$ \\
\hline Obj \% & 8,25 & További leggyak. tart.: Pfl \% & 7,56 \\
\hline További leggyak. tart.: Anat \% & 6,12 & V \% & $45,69^{* *}$ \\
\hline V1: (V2+V3) & $6: 4^{*}$ & Szorongási skála $\%$ & 14,19 \\
\hline
\end{tabular}

* Az átlagértéket a mutatóban használatos formára kerekítettük.

**A gyakoriságot a vulger jelentések új listája szerint jelöltük és számoltuk.

A sine morbo populáció jellemzô Felfogótípusa: G - D - (zw)

2. táblázat. A determinánsokból képzett további mutatók átlagértékei a mutatóban használatos formára kerekítve

\begin{tabular}{l|c|l}
\hline Mutató & Átlag & Besorolás \\
\hline Élménytípus & $1: 3,5$ & Extravertált \\
\hline Másodlagos Formula & $4: 4$ & Kiegyenlített \\
\hline MF - ÉT & $2,70^{*}$ & $\begin{array}{l}\text { Eltolódott, } \\
\text { Fokozott intenzitású }\end{array}$ \\
\hline Indulati Típus & $3: 2,5$ & Feszült \\
\hline Indulati Feszültség & 5,5 & \\
\hline
\end{tabular}

*Nem kerekített érték.

\section{Összefüggés a feleletszámmal}

A feleletszám az abszolút számokat tartalmazó mutatók értékét eltérô mértékben befolyásolja. Ahol a korreláció elég erôsnek bizonyult az elôrejelzéshez $\left(r^{2}>0,4\right)$, a feleletszám alapján várható érték nélkülözhetetlen az értelmezéshez. Ez állapítható meg a következô mutatóknál és jelnél: Indulati feszültség, Tartalmi körök száma, T, MF jobb oldala. Azoknál a mutatóknál, amelyeknél a feleletszámmal gyengébb volt a korreláció $\left(0,4 \geq r^{2} \geq 0,3\right)$, a regressziós függvény elôrejelzésre nem alkalmazható, viszont támpontértékú adatnak tartjuk a tapasztalati átlagok alapján létrehozott feleletszám-övezetekben a mutatók jellemzó értékeit is. Ezek az övezetek 10 választól 45-ig terjednek, és a standard jegyzôkönyveinek 95\%-a idetartozik. A következó mutatókat érinti ez a feldolgozás: IT bal és jobb oldala (V2 + V3), ÉT jobb oldala. Az abszolút számokból álló többi mutatónál vagy mutatóban használt jelnél (MF bal oldala, Td, M, Md csoport, ÉT bal oldala, V1, B) annyira gyenge az összefüggés $\left(r^{2}<0,3\right)$, hogy a feleletszámnak a hatását nem kell figyelembe vennünk. A Felfogótípus kiegészítô jelei közül az alábbiaknál nem állapítható meg összefüggés a feleletszámmal: Gkomb, DGkomb, DzwG, DGkonf, DGkont. 
3. táblázat. A vulger jelentések listája

\begin{tabular}{|c|c|c|c|c|}
\hline Tábla & Lokalizáció & Jelentés & $\begin{array}{c}\text { Gyak. } \\
\%\end{array}$ & Jel \\
\hline I. & $\begin{array}{l}\text { G, Gzw } \\
\text { G, Gzw } \\
1 \\
\text { G, Gzw } \\
\text { G, Gzw } \\
\text { Gzw } \\
\text { Gzw } \\
\text { G }\end{array}$ & $\begin{array}{l}\text { Denevér } \\
\text { Lepke } \\
\text { Bogár, rovar } \\
\text { Bogár, rovar } \\
\text { Madár } \\
\text { Álarc } \\
\text { Állatfej } \\
\text { Falevél }\end{array}$ & $\begin{array}{l}42 \\
28 \\
21 \\
20 \\
11 \\
11 \\
10 \\
8\end{array}$ & $\begin{array}{l}\text { V1 } \\
\text { V1 } \\
\text { V2 } \\
\text { V2 } \\
\text { V3 } \\
\text { V3 } \\
\text { V3 } \\
\text { V3 }\end{array}$ \\
\hline II. & \begin{tabular}{|l|}
1 \\
G, Gzw $(0,20)$ \\
3 \\
$2,3,16$ \\
$17(4,5)$ \\
\end{tabular} & $\begin{array}{l}\text { Négylábú állat, állatbôr } \\
\text { Két ember, két }(\mathrm{M}) \\
\text { Lepke } \\
\text { Vér } \\
\text { Repülő, rakéta, úrhajó }\end{array}$ & $\begin{array}{l}59 \\
15 \\
14 \\
13 \\
10\end{array}$ & $\begin{array}{l}\text { V1 } \\
\text { V3 } \\
\text { V3 } \\
\text { V3 } \\
\text { V3 }\end{array}$ \\
\hline III. & \begin{tabular}{|l|} 
a G \\
2 \\
2 \\
1 és 13 \\
17 \\
c,a Gzw \\
\end{tabular} & $\begin{array}{l}\text { Két ember, két (M) } \\
\text { Csokornyakkendő, masni } \\
\text { Lepke } \\
\text { Kosár, edény, üst* } \\
\text { Cipố } \\
\text { Bogár, rovar vagy az elejük (T, Td) } \\
\end{array}$ & $\begin{array}{l}74 \\
20 \\
15 \\
14 \\
9 \\
8\end{array}$ & $\begin{array}{l}\text { V1 } \\
\text { V2 } \\
\text { V3 } \\
\text { V3 } \\
\text { V3 } \\
\text { V3 }\end{array}$ \\
\hline IV. & $\begin{array}{l}G \\
G \\
4 \text { vagy } 3 \\
\end{array}$ & $\begin{array}{l}\text { Állatbốr, állat } \\
\text { M, (M), Szörny } \\
\text { Csizma }\end{array}$ & $\begin{array}{l}56 \\
43 \\
10 \\
\end{array}$ & $\begin{array}{l}\text { V1 } \\
\text { V1 } \\
\text { V3 }\end{array}$ \\
\hline V. & $\begin{array}{l}G \\
G \\
G \\
\end{array}$ & $\begin{array}{l}\text { Denevér } \\
\text { Lepke } \\
\text { Madár }\end{array}$ & $\begin{array}{l}62 \\
51 \\
19 \\
\end{array}$ & $\begin{array}{l}\text { V1 } \\
\text { V1 } \\
\text { V2 } \\
\end{array}$ \\
\hline VI. & G vagy 1 & Állatbốr, állat & 63 & V1 \\
\hline VII. & \begin{tabular}{|l|}
1,2 \\
1 \\
2 \\
$G$ \\
1,2 \\
\end{tabular} & $\begin{array}{l}\text { Négylábú állat } \\
\text { Émberfej, emberszerú lény feje } \\
\text { Állatfej } \\
\text { Két ember, két }(\mathrm{M}) \\
\mathrm{M},(\mathrm{M})\end{array}$ & $\begin{array}{l}21 \\
19 \\
17 \\
14 \\
12 \\
\end{array}$ & $\begin{array}{l}\text { V2 } \\
\text { V2 } \\
\text { V2 } \\
\text { V3 } \\
\text { V3 }\end{array}$ \\
\hline VIII. & \begin{tabular}{|l}
1 \\
$5(4,2)$ \\
2
\end{tabular} & $\begin{array}{l}\text { Négylábú állat } \\
\text { Hegy, szikla } \\
\text { Lepke }\end{array}$ & $\begin{array}{l}95 \\
24 \\
10 \\
\end{array}$ & $\begin{array}{l}\text { V1 } \\
\text { V2 } \\
\text { V3 }\end{array}$ \\
\hline IX. & \begin{tabular}{|l}
1 \\
2 \\
\end{tabular} & \begin{tabular}{|l|} 
M, (M) \\
Térkép \\
\end{tabular} & $\begin{array}{c}10 \\
9 \\
\end{array}$ & $\begin{array}{l}\text { V3 } \\
\text { V3 } \\
\end{array}$ \\
\hline $\mathrm{X}$. & \begin{tabular}{|l}
6 \\
a,c DzwD \\
$3-13$ \\
$8(9,4,11)$ \\
c $10,3(1,7,5,12$, \\
$24-27)$ \\
4 \\
7 vagy 15
\end{tabular} & $\begin{array}{l}\text { Pók, rák, polip, skorpió, medúza, százlábú } \\
\text { Emberfej, emberszerú lény feje } \\
\text { Négylábú állat } \\
\text { Virág } \\
\text { Virág } \\
\text { Bogár, rovar } \\
\text { Szem }\end{array}$ & $\begin{array}{c}42 \\
14 \\
14 \\
11 \\
10 \\
9 \\
9\end{array}$ & $\begin{array}{l}\text { V1 } \\
\text { V3 } \\
\text { V3 } \\
\text { V3 } \\
\text { V3 } \\
\text { V3 } \\
\text { V3 }\end{array}$ \\
\hline
\end{tabular}

*A III. táblán a kosár, edény és üst mellett az alábbi jelentések is V3-at kapnak: bogrács, bödön, bölcsô, cserép, dézsa, fazék, itató, kancsó, katlan, kád, kehely, kondér, korsó, lavór, lábas, mozsár, mózeskosár, szatyor, szita, tál, táska, teknô, tégely, váza, vödör, zacskó, zsák. 


\section{ÖSSZEGZÉS}

Ennek a tanulmánynak nem célja a kapott eredmények interpretálása vagy összehasonlításuk a korábbi standardok adataival. A Rorschach-rendszerünk revíziója során tett kiegészítések és korrekciók a teszt validitását erôsítik, míg az új standard adatai a kvantitatív elemzéshez nélkülözhetetlen referenciaértékek reliabilitását növelik.

Az új magyar standard célja a Mérei-Rorschach-hagyományt tovább éltetô, megújító munka. Eredményeit biztosabbá teszi, hogy magas elemszámú, rétegzett és kiegyenlített mintára épül, valamint egységes jelöléssel készült. Tovább fejlesztési javaslatainkat indokoltnak tartjuk, a visszajelzések alapján ezeket több Rorschach-képzóhely is alkalmazza már. Valamennyi felhasznált és jelölt jegyzókönyvet elektronikusan tároljuk, ez módot ad a pontos jelölés megtanulására, gyakorlási példatárak közzéadására, és alapot képez további elektronikus feldolgozás kimunkálásához, hasonlóan a Méreirendszeren alapuló Bagdy-Bánsági-féle elektronikus feldolgozáshoz.

\section{KÖSZÖNETNYILVÁNÍTÁS}

Mindenekelôtt vizsgálati személyeinknek köszönjük önzetlen segítségüket, a felvételben való részvételüket és hozzájárulásukat jegyzôkönyvük felhasználásához. Köszönettel tartozunk azoknak is, akik felkutatásukban és beszervezésükben részt vettek.

Köszönjük anonim adományozóinknak az anyagi támogatást, amely a dologi kiadások egy részét fedezte. Egyetlen kérésük az volt, hogy a standard készüljön el.

Köszönjük a Szegedi Tudományegyetem Pszichológiai Intézetének, hogy hozzájárultak a Comprehensive System tanfolyam költségeihez.

Köszönjük prof. dr. Bagdy Emókének és prof. dr. Vargha Andrásnak a többszöri konzultációs segítséget, Takács Johannának az iránymutatásokat a statisztikai feldolgozáshoz, valamint PhD Csigó Katalinnak a szakmai észrevételeket.

Köszönöm a kutatócsoport tagjainak a nehéz, fáradságos, szakmai alázatot, sok idôt és anyagi áldozatot is igénylő, lelkiismeretes, önkéntes munkájukat.

Köszönjük Csizmár Orsolyának és Farkas Kristófnak, hogy a statisztikai próbákat igénylő feldolgozásokat elvégezték.

Különösen köszönöm Molnár Dánielnek, hogy programozóként és rendszergazdaként az informatikai hátteret biztosította, valamint Décsey Dórának, Lázár Eszternek, Rácz Zsuzsannának és Vámos Barbarának, hogy a standardizálás befejezéséig kitartottak.

In memoriam Barlay Mónika Laura. 


\section{IRODALOM}

Bohm, E. B. (1985). Traité du psychodiagnostic de Rorschach. Paris: Huber.

Erikson, E. H. (1988). Der vollständige Lebenszyklus. Frankfurt am Main: Suhrkamp.

Exner, J. E. (2003). The Rorschach: A Comprehensive System. New York: Wiley.

Mérei F. (2002). A Rorschach-próba. Budapest: Medicina Könyvkiadó.

Molnár F., Vámos, B., Lázár, E., Rácz, Zs., Décsey, D., \& Csizmár, O. (2014). A Rorschach-teszt új, hazai standardja. Segédkönyv. Letöltve: 2019. 10. 25. http://rorschach.hu

Pressing L., \& Szakács F. (1990). Az MMPI próba új magyar standardja. Budapest: TBZ kutatás Programirodája.

Rorschach, H. (1998). Psychodiagnostics: A diagnostic test based on perception. Göttingen: Huber.

Tarcsay I. (1940). Pszichodiagnosztika: A Rorschach-vizsgálat és klinikai alkalmazása. Budapest: Királyi Magyar Egyetemi Nyomda.

Vargha A., Császár-Nagy N., \& Bagdy E. (2014). Az életkor és az iskolázottság hatása a Rorschach teszt vulger mutatóira és egyedi vulger válaszaira. Psychologia Hungarica Caroliensis, 2(2), 75-95.

\section{REVIEW OF THE HUNGARIAN RORSCHACH SYSTEM AND THE NEW “SINE MORBO” STANDARD}

\section{MOLNÁR, FERENC}

Background and objective: The elaboration of the new "sine morbo" standard for the Rorschach test started in 2007 and was completed in 2014 by an independent research group at the Institute of Psychology of the University of Szeged. In the preparatory and initial phases of the standardisation process, the Hungarian Rorschach system was re-examined, marking principles were defined, new signs were introduced and several indicators of the Comprehensive System, which are currently being used in most countries, were adopted into our system.

Method: The adult individuals who volunteered to participate in the study were psychiatrically "sine morbo", came from 118 different communities, were aged 18 to 75, and had education levels ranging from primary school to multiple academic degrees. We compiled 32 subsamples from among the categories of the basic independent variables, with a total sample size of 1,500 individuals.

Results: Based on the results, we either reinforced or modified the previous characteristic values and zones of the indicators; determined the reference values of the new indicators and the different effects of the response rate on the signs and indicators; established a list of new vulgar responses; and provided guidance for local interpretation.

Conclusion: The revision of our Rorschach system and the data of the new standard serve as a necessary improvement of the Rorschach test, strengthening its validity and increasing its reliability.

Keywords: "sine morbo" standard, new signs and indicators, further development of the Rorschach test.

A cikk a Creative Commons Attribution 4.0 International License (https://creativecommons. org/licenses/by/4.0) feltételei szerint publikált Open Access közlemény, melynek szellemében a cikk bármilyen médiumban szabadon felhasználható, megosztható és újraközölhetô, feltéve, hogy az eredeti szerzó és a közlés helye, illetve a CC License linkje és az esetlegesen végrehajtott módosítások feltüntetésre kerülnek. (SID_1) 